Prof. Helga Špadina, ${ }^{*} L L . D$.

ПРЕГЛЕДНИ НАУЧНИ РАД

Assistant Professor, Department of Labor and Social Law,

Faculty of Law, Josip Juraj Strossmayer University, Osijek, Croatia

Marina Kalafatić, ${ }^{*}$ Mag. iur.

Osijek, Croatia

UDK: 340.13(4-672EU)

$349.2(497.5)$

Рад примљен: 10.10.2019.

Рад прихваћен: 18.12.2019.

\title{
LEGAL POSITION AND PROTECTION OF WHISTLEBLOWERS IN CROATIAN LAW ${ }^{* *}$
}

\begin{abstract}
In the context of labour relations, legal protection of the so-called "whistleblowers", persons who disclose or expose information on activity deemed illegal, unethical, or incorrect within an organization, is a highly delicate topic which does not cease to attract attention of contemporary labour law. When an employee is ready to report corruptive offences, it is necessary to activate the mechanism of legal protection aimed at protecting the whistleblower from unlawful dismissal and, concurrently, to initiate the procedure for determining the corruptive offence and ensuring clear safeguards to prevent possible abuses by either the employee or the employer. The paper looks into the regulation concerning the protection of rights of whistleblowers in comparative labour law context and the case law of European Court of Human Rights. The authors also analyse the latest efforts by the European Union in the area of legal protection of whistleblowers, as well as the most important European legal instruments. By enacting legal provisions on the protection to whistleblowers, countries actually contribute to the protection of public interest, the advancement of good governance, the strengthening of the rule of law, and the reinforcement of the fundamental democratic right to freedom of expression. In Croatia, almost all publicly known whistleblowers were immediately dismissed and, up to date, only one of them was returned to work on the basis of a court decision. Recently
\end{abstract}

\footnotetext{
*hspadina@pravos.hr *marina0288@hotmail.com

** The paper was presented at the International Conference "Law and Multidsciplinarity", held at the Law Faculty, University of Niš, on 12-13 April 2019. The research was conducted within the project INSPIRED - Innovative Solutions to Refugee and Migration Oriented Education, funded by the EC Erasmus+ (project number: 2017-1-HR01-KA203-035359).
} 
adopted legislative act on the protection of whistleblowers might contribute to changes and might provide long-sought legal protection to all those who report on corruptive practices in their workplaces.

Keywords: protection of whistleblowers, labour law, freedom of expression.

\section{Legal position of Whistleblowers}

Whistleblowers are most commonly defined as "people speaking up when they encounter, in the context of their work, wrongdoing that can harm the public interest, for instance by damaging the environment, public health and consumer safety and public finances" (European Commission, 2019: 55, 66). Transparency International defines whistleblowing as "making a disclosure in the public interest by an employee, director or external person, in an attempt to reveal neglect or abuses within the activities of an organization, government body or company (or one of its business partners) that threaten public interest, its integrity and reputation" (Transparency International, 2019: 4).

According to the Report by the European Commission released in 2017, links between economic benefits and whistleblowers' legal protection should not be overlooked. The Report substantiates its argument that the potential to recover misused public funds exceeds the costs of setting up and maintaining systems of legal protection of whistleblowers (European Commission, 2017:6061). Whistleblowers' reports can lead to effective detection, investigation and prosecution of violations of law that would otherwise remain hidden, causing serious harm to the well-being of society and, generally, to the public interest (European Commission, 2017:13).

There is a valid question why we would need to protect whistleblowers, and the answer to that question is rather simple. The European Commission conducted a survey in 2017 and published the results in the Special Eurobarometer on Corruption; $81 \%$ of respondents said that they did not report the corruption that they had experienced or witnessed. Similarly, $85 \%$ of respondents to the Commission's 2017 public consultation expressed the view that employees very rarely report concerns about threat or harm to the public interest. Fear of legal and financial consequences was the most widely cited reason for not reporting the wrongdoing. Whistleblowers face high risks of retaliation, ranging from being demoted to being brought to court, losing their jobs and economic stability (European Commission, 2017:16, 25, 28). 


\section{European Union efforts in the Area of Legal protection of Whistleblowers}

In April 2019, the EU adopted new standards on the protection of persons reporting breaches of the EU law in a wide range of areas, including public procurement, financial services, money laundering, product and transport safety, nuclear safety, public health, consumer and data protection. The Directive (EU) $2019 / 1937$ on the protection of persons who report breaches of Union law ${ }^{1}$ entered into force in December 2019 and is about to be incorporated into the national legislation of all EU Member States.

Those rules envisage safe reporting channels allowing whistleblowers to disclose information either internally to the legal entity concerned or directly to competent national authorities, or externally to relevant EU institutions, bodies, offices and agencies. In addition to helping the whistleblowers, these rules should have significant impact on the confidentiality of information. The EU has also established safeguards against retaliation explicitly prohibiting reprisals and introducing safeguards to prevent the whistleblower from being suspended, demoted and intimidated, or facing other forms of retaliation. EU rules also protected persons who were assisting whistleblowers, such as facilitators, colleagues or relatives. Access to comprehensive and independent information and advice on available procedures and remedies, legal aid during proceedings, and financial and psychological support should be free-of-charge (European Commission, 2017:48).

Whistleblower protection currently provided in the European Union is fragmented across Member States and uneven across policy areas. Currently, only ten EU countries (France, Hungary, Ireland, Italy, Lithuania, Malta, Netherlands, Slovakia, Sweden and United Kingdom) have a comprehensive law protecting whistleblowers. In the remaining EU countries, the protection granted is partial: it covers only public servants or only specific sectors (e.g. financial services) or only specific types of wrongdoings (e.g. corruption). (European Commission, 2017:60).

1 Directive (EU) 2019/1937 of the European Parliament and of the Council of 23 October 2019 on the protection of persons who report breaches of Union law; the Directive officially entered into force on 16.12.2019 as Directive 2019/1937; available at: https://eur-lex.europa. eu/legal-content/EN/TXT/PDF/?uri=CONSIL:PE_78_2019_REV_1\&from=EN. 


\section{Comparative overview of Protection of Whistleblowers in the UK, Sweden and France}

\subsection{United Kingdom}

The UK is one of the few countries where the protection of whistleblowers is fully regulated by law. The Public Interest Disclosure Act was enacted in 1998 to protect whistleblowers and is linked to the Employment Rights Act of 1996, which generally regulates employee rights. The law applies to the private and public sectors, with the exception of military and intelligence personal. An employee has the right to protection if he or she publicly discloses information related to the commission of a criminal offense, failure to fulfill a legal obligation, alleging misapplication of rights, endangering the health and safety of an individual, destroying the environment and intentionally concealing information that reveals one of these situations. All these situations can be reported to the employer, legal representative, minister, external body and the media. The law itself protects "whistleblowers" from discrimination and retaliation in the form of unlawful dismissal, inability to make further business progress, or exclusion from further training opportunities. The difference between internal and media release of information is important. Media disclosure is desirable only if it has been unsuccessful internally, or if there is reasonable suspicion that it will be disadvantageous to the employee. Employment Tribunals were established as special courts dealing with the issue of violations, such as discriminatory conduct and termination of employment contracts. In determining whether a particular disclosure was reasonable, the court must consider all the circumstances, including the identity of the person to whom the information was disclosed, the seriousness of the matter reported, whether the risk or danger still existed, and whether the disclosure violated the confidentiality obligation of the employer to a third party. Regarding compensation, the Public Interest Disclosure Act stipulates that there is no limit on the amount of compensation paid to persons who have been unjustifiably dismissed for "whistleblowing". If the whistleblower is dismissed, he/she may report it to the court dealing with the violation of employees' rights and ask the court to issue a temporary order to keep his/her job while the proceedings are pending. If it is proven in court that the employee was fired for disclosing information, the court may decide that the employee is entitled to be reinstated or that he/she is entitled to monetary compensation (Centar za razvoj nevladinih organizacija, 2017).

\subsection{Sweden}

Sweden, like most other European countries, does not have a lex specialis aimed at protecting whistleblowers. Freedom to provide information to the media is 
regulated through two constitutional laws. According to the Media Freedom Act, every person has the right to freedom of expression in the media. Freedom of speech implies the right of every Swedish citizen to publish certain content without being sued for the content of the publication, unless it is content whose publication is prohibited by express provisions of the law. In accordance with the provisions contained in the Act on the Protection of Personal Rights and Public Safety, every Swedish citizen is free to express his/her opinion, publish official documents, and publish information and intelligence on any topic. The right to send information must be distinguished from that of the person providing the information. There are some exceptions to the right to send information. The provision of information for publication in a book or newspaper is not permitted if the person providing the information thus commits a serious crime against Sweden's national security, the intentional disclosure of an official document whose publication is secret and the intentional breach of certain obligations of secrecy are not permitted. Secrecy obligations that replace the right to provide information are enumerated in the Secrecy Act and in the Freedom of the Media Act. The right to provide and share information is protected by the right to anonymity and professional secrecy for journalists and other media representatives (Ministarstvo pravosuđa Republike Hrvatske, 2009:8). The protection of the person who provided the information also includes a ban on the authorities trying to reveal his/her identity; a person who intentionally or negligently reveals his/her identity without permission or neglects the obligation to ensure anonymity will be punished by a fine or imprisonment for up to one year. In case of proceedings on determining liability for publication, there is only one person who can be held liable for illegal content, while all others who contributed to the publication are, in principle, exempted from liability.

\subsection{France}

France also does not have a lex specialis on the protection of whistleblowers, but their protection is regulated through the Labor Code and the Civil Servants Act. There is a difference in protection between public and private sector employees. For the private sector, special safeguards have been introduced in the Labor Act, under which no employee can be removed from the hiring, internship or training process, nor can he/she be punished, dismissed, or subject to discriminatory measures, direct or indirect, especially in the context of employment income and promotion, as a result of acting in good faith and disclosing corruption facts that he/she has become aware of in the course of the performance of his/her professional duties and responsibilities to his/her employer, administrative or judicial authorities. If a claim arises on these counts, the employer has to prove that his decisions are justified by objective facts, independent of the employee's 
allegations or testimonies, and the burden of proof principle is reversed. As for the public sector, the legislator did not consider it necessary to amend the existing legislation because civil servants were deemed to be sufficiently protected by their (public) status. Civil servants are subject to the provisions of Art. 40 (2) of the French Criminal Procedure Code, which states that all established authorities, all public officials and civil servants who, in the course of their professional activity, obtain knowledge of a crime or a misdemeanor are obliged to inform the public prosecutor without delay and pass on to him all information, court hearings and related acts (Ministarstvo pravosuđa Republike Hrvatske, 2009:3). French theorists believe that it is not necessary to ensure the protection of "whistleblowers" by a separate law. They believe that despite lex specialis, employees will find it difficult to protect themselves against discrimination, and that such law leads to malicious competition, a conflict situation, and that officials and officers will spy on one another. They also believe that adoption of a lex specialis would be a sign of the inefficiency of the judiciary; it would mean that the bodies conducting the prevention and repression are ineffective (Habazin, 2010:342).

\section{Legal Protection of Whistleblowers in Croatia}

\subsection{Act on Protection of Irregularity Reporters (Whistleblowers)}

After more than ten years of deliberations and discussions about the proposal of the law aimed at providing comprehensive legal protection to whistleblowers in Croatia, the new Act on Protection of Irregularity Reporters (Whistleblowers) ${ }^{2}$ was adopted and has been in force since July 2019. The Act regulates the reporting of irregularities, the procedure for reporting irregularities, the rights of persons reporting irregularities, the obligations of public authorities and legal and natural persons in relation to reporting irregularities, as well as other issues important for reporting irregularities and protecting whistleblowers. Article 5 of this Act strictly and explicitly prohibits prevention of reporting of irregularities, and any such prohibition would be null and void. It is explicitly prohibited to put whistleblower into a disadvantaged position by termination of employment contract, termination of civil service, harassment, impossibility of promotion, failure to pay and reduction of salary and other benefits, initiation of disciplinary proceedings, imposition of disciplinary measures or penalties, denial of work tasks, change of employment time, disabling education and training, failure to pay benefits and severance pay, scheduling or transferring to

2 Zakon o zaštiti prijavitelja nepravilnosti (Act on the Protection of Irregularity Reporters/ Whistleblowers), Narodne novine br. 17/19, https://www.zakon.hr/z/1927/Zakon-o-zaštitiprijavitelja-nepravilnosti (accessed 10 Dec. 2019). 
another workplace, failing to take measures to protect the workers' dignity from harassment by others, arbitrary referrals to health or work screening, and other adverse treatment. The whistleblower is entitled to protection of identity, protection of confidentiality, and legal assistance for reporting irregularities, as well as to compensation for damages (Articles 9-12). Reporting irregularities can be internal and external; exceptionally, it may entail public disclosure if there is an imminent danger to life, health, safety, or from large-scale damage or destruction of evidence (Article 23). The Act also regulates obligations of the employer who should ensure the possibility of internal reporting of irregularities, appoint a confidential person for internal reporting of irregularities on the proposal of at least $20 \%$ of the employees employed by the employer, and protect the whistleblower from adverse action. The employer should also undertake the necessary measures to stop the harmful actions and remedy their consequences, keep the information received in the application and prevent its unauthorized disclosure, unless contrary to law, and take measures to eliminate identified irregularities as per Article 17 of the Act. Finally, the Act regulates the judicial procedure, involvement of third parties, infringements and applicable fines.

\subsection{Labor Act}

Only one article of the Croatian Labor Act $^{3}$ contains provisions on the protection of whistleblowers, stating unjustified reasons for dismissal. The provision of Article 116 stipulates that the filing of a complaint or a lawsuit, or participation in proceedings against an employer for violation of a law, a bylaw, a collective agreement or a regulation, or an employee's report of irregularities to the competent bodies of the executive power does not constitute a justified reason for termination of a contract of employment. In addition, an employee's report of irregularities for a justified suspicion of corruption or filing a report (in good faith) on that suspicion with the responsible persons or competent bodies of state government does not constitute a justified reason for termination of the employment contract. In order to provide legal protection against dismissal to an employee who has alerted about criminal offense, both assumptions must be fulfilled cumulatively; thus, there must be a justified suspicion of corruption and a report must be submitted to the responsible persons or competent bodies of state government (Rajko, 2007:114).

There is a risk that a dismissal motivated by some of the aforesaid reasons may be covered up with another dismissal basis. The aforementioned provisions also apply to employees who are covered by special regulations governing

3 Zakon o radu (Labour Act), Narodne novine br. 93/14, 127/17, 98/19, available at: https:// www.zakon.hr/z/307/Zakon-o-radu (accessed 10 December 2019). 
employment, as they regularly refer to the indirect application of general labor law rules. From the above, we conclude that employees are obliged to report corruption to the competent authorities, but they must be prepared to bear the negative consequences that affect them.

\subsection{Civil Servants Act}

In the Civil Servants Act ${ }^{4}$, the protection of "whistleblowers" by employees within state institutions is contained in the chapter on fundamental rights of civil servants. The provision of Article 14a stipulates that a civil servant's report of irregularities for a justified suspicion of corruption or filing a report on suspicion of corruption to responsible persons or competent state bodies does not constitute a justified reason for termination of service. If the competent authority considers that this is a serious form of corruption, the civil servant shall be guaranteed protection of anonymity, protection against denial or restriction of the rights established by this Act and protection against any form of abuse. The head of the body is obliged to initiate proceedings against a leading civil servant for grave breach of duty if he/she in any way discriminates against a civil servant who has reported a corruptive offence. The Act stipulates that a civil servant is obliged to report a justified suspicion of corruption; otherwise, it constitutes a serious breach of official duty. Article 27 of the Civil Servants Act contains a provision excluding the liability of a civil servant who warns or notifies the competent person about an illegal order. It also prescribes the duty of a civil servant to refuse to execute an illegal order, or an order whose execution would be contrary to the rules of the profession and the code of ethics, or an order whose execution could cause major damage, or an order whose execution would constitute a criminal offense. A civil servant who has been ordered to execute an unlawful order is obliged to warn the provider of such an order of illegality; in the case of a repeated order, a civil servant has to require from the order provider to give a written confirmation of the repeated order, including precise contents of the order and the signature of the person who issued the order. If the order is confirmed, the civil servant will notify the person immediately superior to the person who issued the order and execute the order if it does not entail the commission of a crime. If he executes an order which entails a commission of a crime, he/she will be liable together with the head of the body or the superior who issued the order. Article 99 (point 10) of the Civil Servants Act states that limiting or denying the rights established by

4 Zakon o državnim službenicima (Civil Servants Act), Narodne novine br. No 92/05, 142/06, 77/07, 107/07, 27/08, 34/11, 49/11, 150/11, 34/12, 49/12, 37/13, 38/13, 01/15, 138/15, $61 / 17,70 / 19,98 / 19$, available at:

https://www.zakon.hr/z/108/Zakon-o-državnim-službenicima (accessed 10 December 2019). 
this Act to a civil servant who reports a case of suspected corruption or the civil servant's abuse to a responsible person or competent authority constitutes a serious breach of official duty.

\subsection{Act on Civil Servants and Employees in Local and Regional Self-Government}

The Act on Civil Servants and Employees in Local and Regional Self-Government ${ }^{5}$ contains Article 32 on the right of civil servants and employees to report suspected corruption, which explicitly states that failure to report a justified suspicion of corruption constitutes a serious breach of official duty. Article 32 regulates that justified suspicion of corruption or the submission of a report on that suspicion to responsible persons or competent state bodies does not constitute a justified reason for termination of service. This Act also guarantees employees protection of anonymity, protection against denial or restriction of rights, and protection against any form of abuse. If the whistleblower is in any way denied the protection of guaranteed rights, the head of the administrative body is obliged to institute proceedings for grave breach of official duty against the managing officer. If an official or an employee abuses their obligation to report a justified suspicion of corruption, it is considered a grave breach of official duty.

\subsection{Trade Act}

Article 57 of the Trade Act ${ }^{6}$ regulates the employees' rights to file a complaint, a lawsuit or initiate proceedings against the employer for violation of the law and report corruption to the competent institutions. It is stipulated that such a complaint cannot be a justified reason for dismissal, and anonymity is guaranteed to the whistleblower. An employee's report of irregularities to a government authority, filing a complaint or a lawsuit, filing a good faith allegation of corruption against responsible persons and participating in proceedings against an employer for violation of the law, regulations, collective agreement or rulebook may not be grounds for termination of an employment contract. An employee who files a complaint on reasonable suspicion of corruption shall be guaranteed anonymity, protection against the denial or restriction of the rights laid down in labor regulations and protection against any form of abuse.

\subsection{Other relevant domestic laws}

5 Zakon o službenicima i namještenicima u lokalnoj i područnoj (regionalnoj) samoupravi (Act on Civil Servants and Employees in Local and Regional Self-Government), Narodne novine br. 86/08, 61/11, 04/18112/19, available at: https://www.zakon.hr/z/259/Zakon-oslužbenicima-i-namještenicima-u-lokalnoj-i-područnoj-samoupravi (accessed 10 June 2019). 6 Zakon o trgovini (Trade Act), Narodne novine br. 87/08, 96/08, 116/08, 76/09, 114/11, 68/13, 30/14, 32/19, 98/19, available at: https://www.zakon.hr/z/175/Zakon-o-trgovini (accessed 10 December 2019). 
Croatian legislation contains provisions on the protection of whistleblowers in several other legislative acts. Article 24 of the Act on Protection of Confidentiality of Data ${ }^{7}$ regulates the exemption from breach of business secret if a person who has knowledge about confidential information reports a criminal offence, a business or other misdemeanor to a competent body, and if he/she reports it in order to exercise one of his/her labor rights. Further, Article 43 (6) of the Act on the Internal Financial Control System in the Public Sector ${ }^{8}$ regulates matters related to whistleblowing, particularly reporting irregularities, appointment of employee in charge of receiving complaints, yearly submission of reports on reported irregularities, and legal protection to whistleblowers. The Criminal Procedure Act ${ }^{9}$ also regulates the obligation to report crimes, and whistleblowing could be considered under Article 204 of the Criminal Procedure Act.

\section{Case Law of the European Court of Human Rights}

\subsection{Guja v. Moldova (Application no. 14277/04), Judgment of 12 February 2008}

Mr. Iacob Guja worked as the Head of Public Relations at the Attorney General's Office of Moldova. In 2003, he publicly presented evidence of political interference in a criminal case against four police officers who were accused of mistreatment of suspects, or of exceeding their powers. Deputy Speaker of the Parliament wrote a letter to prosecutors requesting criminal charges, but the case was subsequently closed. Mr. Guja sent a letter to the newspaper and was subsequently fired. The European Court of Human Rights has ruled in Guja's favor. The Court states that there is no doubt that these are very important issues in a democratic society and that the public has a legitimate interest in being informed. As a rule, decisions relevant to "whistle-blowing" refer to the interpretation of Article 10 of the European Convention for the Protection of Human Rights and Fundamental Freedoms (ECHR), which regulates the right to freedom of expression. The Court states that the right to freedom of expression also includes the right to disseminate information received by third parties.

7 Zakon o zaštiti tajnosti podataka (Act on Protection of Confidentiality of Data), Narodne novine 108/96, available at: https://www.zakon.hr/z/748/Zakon-o-zaštiti-tajnosti-podataka (accessed 10 June 2019).

8 Zakon o sustavu unutarnjih kontrola u javnom sektoru (Act on the Internal Financial Control System in the Public Sector), Narodne novine br. 78/15, 102/19, available at: https:// www.zakon.hr/z/806/Zakon-o-sustavu-unutarnjih-kontrola-u-javnom-sektoru (accessed 10 June 2019).

9 Zakon o kaznenom postupku (Criminal Procedure Act), Narodne novine br. 152/08, 76/09, 80/11, 121/11, 91/12, 143/12, 56/13, 145/13, 152/14, 70/17, 126/19, 126/19, available at: https://www.zakon.hr/z/174/Zakon-o-kaznenom-postupku (accessed 10 June 2019). 
Article 10 ECHR extends to the workplace in general and public officials in particular. According to the Court, employees have a duty of loyalty, restraint and discretion towards their employers, which includes a duty of moderation when disseminating information, regardless of the accuracy of the information. The Court considers that the signaling, by a civil servant or an employee in the public sector of illegal conduct or wrongdoing in the workplace should, in certain circumstances, enjoy protection against interference. The Court further clarified that information should first be transmitted to the superior or other competent authority, and only where this is clearly inapplicable, as a last resort, the information may be made public. It is necessary to determine whether the public interest in disclosing particular information outweighs the duty to protect the confidentiality of information, taking into account the truth of the information and the motive of the whistleblower (Rajko, 2011a: 69).

5.2. Heinisch v. Germany (Application no. 28274/08), Judgment of 21 July 2011

Ms. Brigitte Heinisch worked at a Berlin nursing home. In 2005, she was dismissed for notifying the public of poor treatment of home users. The users lived in poor hygienic conditions and were often bed-bound even though the staff did not have a court order or the necessary medical records for such a procedure. Ms. Heinisch reported that the institution lacked staff and that the problem was concealed by false reports. She distributed brochures detailing all the problems she encountered working in that nursing home owned by the city of Berlin. Several German courts ruled against Ms. Heinisch's reinstatement to her previous job. One judge found that she should not be protected from dismissal or returned to work because the criminal complaint she filed against the institution she worked for did not result in the indictment being brought against the institution and employees. The European Court of Human Rights ruled in favor of Ms. Heinisch.

\subsection{Bucur and Toma v. Romania (Application no.} 40238/02), Judgment of 8 January 2013

Mr. Constantin Bucur was an employee of the Romanian Intelligence Surveillance and Recording Division. In 1996, he held a press conference announcing that the Romanian intelligence service was eavesdropping on journalists, politicians, and the business world. He was dismissed and convicted in 1998 of unlawful disclosure of classified information. Fifteen years later, the European Court of Human Rights ruled that the Romanian Government had violated Mr. Bucur's right to freedom of expression. ${ }^{10}$

10 Bucur and Toma v. Romania (Application no. 40238/02), Judgment of 8 January 2013, available at: https://hudoc.echr.coe.int/eng\#\{\%22itemid\%22:[\%22001-115844\%22]\}, 
5.4. Marunic v. Croatia (Application no. 51706/11), Judgment of 28 March 2017

Ms. Mirela Marunić was a director in the public utilities company Kostrena from Croatia. During 2007, the Chairman of the the General Assembly of the company criticized the work of the director in the media, which resulted in poor performance and insufficient business results. Ms. Marunic responded in the same way, through the media, warning that the utilities company illegally charged parking on certain parking lots, and called in the state audit, State Office for Prevention of Corruption and Organized Crime, and the police to monitor the work of the company. On the basis of her media appearance and alleged violation of the reputation of the utilities company, her employment contract was terminated. The Croatian courts passed several judgments in which they found that the termination of the employment contract was lawful. The European Court of Human Rights considered that plaintiff had the right to respond to public criticisms in the same way as they were addressed, and that she did not violate her obligation of loyalty to her employer in her statements. The Court awarded the plaintiff just satisfaction in the amount of EUR 1,500 in respect of the sustained non-pecuniary damage. The Court argued that the plaintiff's right to freedom of expression had been violated by termination of her employment contract.

\subsection{Martin and Others v. France (Application no.} 30002/08), Judgment of 12 April 2012

In 2005, journalists of the French newspaper Midi Libre published an article stating that the Regional Court of Auditors in one French region had criticized the leadership of that region. Parts of the draft report were cited in the article, although the contents of the report were still regarded as confidential information. A criminal complaint was filed against the journalist for breach of professional secrecy and use of classified documents. The court stated in its reasoning that the applicants (journalists) had published portions of the draft report of the Regional Court of Auditors, citing mainly information on how local politicians and officials managed public funds. The Court found that the topic of the article was undoubtedly in the general interest of the local community and that journalists had every right to inform the public. The articles at issue were published in the context of a public debate on a matter of interest of the local population, which has the right to be informed. The role of investigative journalism is precisely to inform and alert the public of undesirable social phenomena as soon as journalists obtain some relevant information. Considering that the journalists noted on the front page that it was an unofficial (preliminary) report on an ongoing

accessed 15 June 2019. 
investigation, the Court considered that they had demonstrated good faith and concern for observing the rules of professional ethics.

\section{Croatian Case-Law on Whistleblowing}

Case 1: Ms. Ankica Lepej is the first "whistleblower" well-known in the media. After the publication of a newspaper article about the savings of Ms. Ankica Tudjman, the wife of then President of the Republic of Croatia, Ms. Lepej made a statement that she, as a bank employee, was the source of the information. The savings were not reported on the official property card of the President of the Republic of Croatia. In November 1998, the Zagreb Municipal State Attorney's Office instituted criminal proceedings against Ms. Lepej for the criminal offense of treason and the misappropriation of a business secret. Before the main trial, the State Attorney's Office dropped the prosecution and the court adjourned the proceedings (Pavlović, 2007:201). In parallel with the prosecution, she received an extraordinary termination of her employment contract. In the dismissal decision, the bank management alleged that she had committed particularly grave breaches of her employment obligations, such as: the abuse of office, exceeding the given authorization, and disclosure of business secrets. The basic law in the Croatian banking system is the Banks Act. ${ }^{11}$ It elaborates on the legal nature of confidential information, the obligation to keep bank secrecy, and the use and protection of confidential information. The question was whether she was allowed to disclose the information to third parties, and in doing so, whether she acted against the interests of the bank and clients. The State Attorney's Office was mistaken in qualifying the offense as a criminal offense against payment security and business disclosure, and unauthorized disclosure of business secrecy (Pavlović, 2007:203). We can conclude that it can only be a criminal offense against the freedom and fundamental rights through unauthorized disclosure of a business secret. The proceedings could also be subject to the legal ground of exclusion of unlawfulness, since the disclosure of a secret is in the general interest or in the interest of another person which outweighs the interest of keeping the secret. Ms. Lepej never initiated a labor dispute, nor was she reinstated to her previous employment.

Case 2: Mr. Zoran Prpić was a pilot at the national airliner Croatia Airlines. His employment contract was terminated due to several statements published in a daily newspaper, where he informed the public about the state of security in the airline and the hiring policy for directors (Peček, 2017:6). He filed a lawsuit

11 Zakon o bankama (Banks Act), Narodne novine br. 84/02, 141/06, available at: https://narodne-novine.nn.hr/clanci/sluzbeni/1998_12_161_1983.html (accessed 10 December 2019). 
against the former employer. After examining the extensive evidence, the trial court rendered a judgment finding the nullity of the decision to terminate the employment contract and ordered the defendant to return the applicant to his workplace and his post of a pilot. The court of second instance upheld the position of the court of first instance. Acting on defendant's appeal, the Supreme Court upheld the defendant's view, reversed the judgments of the court of first and second instance, and rejected the applicant's claim seeking a declaration of nullity of the employment contract, reinstatement and payment of unpaid wages. The Court reasoned that the trial court based its judgment on the fact that, prior to the decision to terminate the employment contract, the defendant (Croatia Airlines) had not alerted the plaintiff/claimant (Prpić) in writing about his employment obligations and about the possibility of dismissal in the event of continued breach of obligations, which the defendant was obliged to do under the Company's Rules of Procedure. However, the Supreme Court held that the defendant's omission in the particular case was not of such character that would make the termination of the employment contract and the disputed dismissal inadmissible and unlawful. Subsequently, Zoran Prpić filed a constitutional complaint, which was unanimously rejected by a decision of the Constitutional Court. When filing a lawsuit, he invoked the constitutionally guaranteed freedom of thought and expression, which also includes the freedom to receive and impart information. In the present case, the Constitutional Court considered relevant the legal positions set out in the ECtHR case Balenovic v. Croatia (2009). The court found that his appearance in the press was motivated by personal dissatisfaction and inability to get promoted, not by concern for the safety of passengers.

Case 3: Ms. Vesna Balenovic was an employee of petrol company INA and she warned of irregularities in the Petroleum Products Transport Sector. Working as an Economic Affairs Specialist for the Director of the Logistics and Transportation Department, she had an immediate insight into oil transportation and the movement of tanks. She soon realized that the transportation of oil actually involved a number of manipulations, due to which INA sustained considerable financial losses. The company management was responsible for irregularities, such as: organized theft of derivatives, the conclusion of risky contracts, mismanagement, bargaining, and the violation of public procurement laws in extremely high amounts. Instead of checking her allegations, her superiors simply terminated her employment contract. In addition to the extraordinary dismissal, five separate legal proceedings were instituted against her for alleged mental anguish and defamation, and seven-year prosecution proceedings resulted in 41 hearings, and imprisonment and fines. She was never returned to her workplace. She brought before the European Court of Human Rights. The applicant complained under Article 9 (freedom of thought) and Article 10 (freedom of expression) 
of the Convention because of the termination of her employment contract and because the domestic courts in the civil proceedings subsequently refused to return her to work. She also claimed the violation of Article 14 of the Convention (prohibition of discrimination) as she was discriminated against for expressing her opinion, as well as the violation of Article 6 of the Convention (right to a fair trial) because of the outcome of the civil proceedings and because the Constitutional Court of the Republic of Croatia was not impartial. Lastly, under Article 13 ECHR (right to effective remedy), the applicant complained that she did not have an effective remedy to protect her freedom of expression. Regarding the alleged violation of Article 10 ECHR, the Court considered that interference with the freedom of expression in this case was lawful and pursued the legitimate objectives; the only question to be determined by the court was whether interference was "necessary in a democratic society". The Court reiterated that Article 10 ECHR does not guarantee a completely unrestricted freedom of expression and that the exercise of that freedom carries with it certain duties and responsibilities. Therefore, although the applicant's dismissal was a harsh punishment for her conduct, the Court concluded that the interference was not disproportionate to the legitimate aim pursued and could therefore be considered "necessary in a democratic society". The Court rejected the complaint as manifestly inadmissible. Taking into account the alleged violation of Article 14 ECHR, the Court could find no reason to conclude that the dismissal was based on any discriminatory elements. Regarding the alleged violation of Article 6 ECHR, the Court considered that the relationship between Constitutional Judge A.R. and Supervisory Board Chairman S.L. was so distant and remote that this relationship could not justify her concern that the Constitutional Court was not impartial. The applicant did not provide any evidence suggesting that Judge A.R. was personally biased. The Court also dismissed claim on non-availability of an effective legal remedy for the protection of the applicant's freedom of expression (Rajko, 2011b: 67). Vesna Balenovic founded the Whistleblower Association in 2008. This non-governmental, non-profit, non-partisan organization is committed to the full protection of the human and labor rights of individuals who, warn of crime, corruption and contempt of law in their communities. Shortly after the President of the Republic of Croatia appointed her the Commissioner for Whistleblowers, Vesna Balenovic was relieved of her duties. She believes that she has been appointed to this post for formal reasons, without a sincere desire for co-operation and intent to really help the "whistleblowers" and fight against crime and corruption (Gavran, 2016: 34).

Case 4: Ms. Jasmina Jovev was the head of the Office of the former Sisak-Moslavina County. Marina Lovrić Merzel was Mayor who publicly uncovered corruption and was fired. Her job was to fake reports for county advisory bodies, and forge 
documentation related to representation expenses bills. The County Advisory Bodies were fictitious bodies that received millions annually from the budget for activities they did not perform. These are illegal fees paid without any work, just to secure a majority in the County Assembly. After she disclosed the information to the public, Mayor Marina Lovrić Merzel was arrested under the charges of corruption. The trial is still ongoing. In October 2013, Jovev was declared technologically redundant and placed in the non-allocated status. Subsequently, her case got under the jurisdiction of the Civil Service Tribunal, before which the Sisak-Moslavina County sought dismissal for breach of duty. Jasmina Jovev objected to the County's dismissal, the Labor Inspectorate investigated the case further and, finding irregularities, cancelled the dismissal decision. Jasmina Jovev is one of the few whistleblowers in Croatia who returned to her workplace.

Case 5: Mr. Srećko Sladoljev is a biologist and an immunologist who was suspended from his post at the Immunological Institute for publicly criticizing the administration for its non-transparent and harmful deal concerning the sale of vaccines. In 2009, he declared swine flu vaccination as a conspiracy of the media and pharmaceutical companies. Through numerous media appearances, he tried to make citizens aware of the fraud of the pharmaceutical industry. He was returned to his post and is still fighting for the survival of the Immunological Institute. He was invited to Brussels to participate in the drafting of the European Whistleblower Directive.

\section{Conclusion}

The adoption of new law on the protection of whistleblowers in Croatia is very timely since it occurred three months after the adoption of EU Directive on protection of whistleblowers which will become legally binding to all Member States (including Croatia) after the approval by EU ministers. Thus, we can say that national legal protection of whistleblowers in Croatia was conditioned by the initiative from the EU level and imminent obligation to align national laws with the EU acquis. Therefore, it is no surprise that Croatian law follows provisions of the proposed EU Directive and has adopted its main features.

Having in mind the national case-law analyzed, primarily the cases of Lepej, Prpic and Balenovic in which all whistleblowers got dismissed and national courts justified those dismissals, failing to provide them basic legal protection, the adoption of a lex specialis in this area was a necessity and conditio since qua non for the employers, Croatian courts and overall public. Although it may seem that whistleblowers are only those who are publicly known, the practice is often different; a majority of whistleblowers at workplace in Croatia, but also in other countries, remains anonymous. We have to emphasize a stark difference 
between Lepej and Prpić cases and Balenovic case because, in the latter, both national courts and the ECtHR found no legal grounds to justify whistleblowing.

In terms of employers, a significant step forward in the new law are provisions specifying the employees' obligations regarding the establishment of procedures for internal reporting, the legal protection of the whistleblower, and duty to undertake measures to remedy all irregularities, which might lead to improved legal protection of whistleblowers. Unfortunately, new law does not explicitly address procedure in which whistleblower would need to report on wrongdoings of direct supervisor who is at the same time the employer; but, we assume this case would be eligible for external reporting to the Ombudsperson. Explicit prohibition of discriminatory treatment of whistleblower in all areas of employment and work is also important for the comprehensive legal protection of whistleblowers, particularly considering that termination of employment contract is not the only retaliation measure whistleblowers can experience. Inability to get promoted, denial of access to professional trainings, harassment and other forms of retaliation are very common in the workplace as a direct consequence of reporting irregularities.

In terms of courts, the adoption of the new national law on whistleblowers' protection, along with EU Directive, will send a clear message to courts that whistleblowing plays "a key role in exposing and preventing breaches of the law that are harmful to the public interest and in safeguarding the welfare of society" (EU Directive, 2019).

In terms of public, it is still necessary to raise national awareness on the public benefits of disclosure of corruptive practices and other criminal activities, as well as to remove social stigma often labeling whistleblowers as "traitors." As long as whistleblowers are perceived in a negative light in the public eye, we will have under-reporting of criminal activities in the workplace and reluctance to report irregularities. Detecting fraud, corruption, illegal activities, unlawful performance, theft, possible endangering of human lives and other criminal activities should be viewed by public as a humane, beneficial and heroic act (rather than the opposite). If national laws do not provide comprehensive legal protection of whistleblowers, we cannot speak of state's commitment to successfully prevent crime. Ensuring legal support to whistleblowers could lead to public welfare and rule of law. 


\section{References}

Gavran, D. (2016). Kako djeluju odnosi s javnostima tvrtke koja je na meti zviždača (analiza slučaja INA d.d.-V.Balenović), Diplomski rad, Sveučilište Sjever, Sveučilišni centar Varaždin; available at https://repozitorij.unin.hr/islandora/ object/unin:711

Habazin, M. (2010). Zaštita „zviždača“, Hrvatska javna uprava, No.2, (331-348). Zagreb.

Pavlović Š. (2007). Fragmenti o položaju i zaštiti „zviždača“u hrvatskom pravnom sustavu, Aktualna pitanja kaznenog zakonodavstva, str. 195-254, Zagreb.

Peček R. (2016).Sloboda izražavanja u nekim specifičnim pravnim situacijama, Informator br. 6450-6451 (str.6-7), Zagreb.

Rajko A. (2007). Radnopravni položaj „zviždača“, Financije i porezi br.8. (str.112114), Zagreb.

Rajko, A. (2011a). "Zviždanje” iz perspektive slučaja Balenović protiv Hrvatske, Radno pravo, br.2 (str.27-36), Zagreb.

Rajko, A. (2011b). Praksa europskog suda za ljudska prava vezana za „zviždače“, Pravo i porezi, br.5 (str.64-70), Zagreb.

\section{Web sources:}

Centar za razvoj nevladinih organizacija (2017). Zaštita zviždača-terorija i praksa https://epale.ec.europa.eu/sites/default/files/brosura_zastita_zvizdaca_web.pdf; retrieved 10 April 2018.

European Commission (2017). Estimating the Economic Benefits of Whistleblower Protection in Public Procurement (Final Report, by Millieu Ltd), Brussels, 2017, available at: https://publications.europa.eu/en/publication-detail/-/ publication/8d5955bd-9378-11e7-b92d-01aa75ed71a1/language-en

Ministarstvo pravosuđa RH (2009). Analiza zaštite zviždača u državama članicama Europske Unije-pregled legislative, izvješća i mišljenja (Croatian Ministry of Justice, Analysis of Whistleblowers' Protection in EU Member States), Ministarstvo pravosuđa Republike Hrvatske, https://pravosudje.gov.hr/userdocsimages/ arhiva/Root\%20Folder/Zvizdaci\%20EU_analiza.pdf (retrieved 10 April 2018)

Transparency International (2019), International Principles for Whistleblowers Legislation, available at: https://www.transparency.org/whatwedo/publication/international_principles_for_whistleblower_legislation (accessed 15 June 2019). 
Legislation

Zakon o zaštiti prijavitelja nepravilnosti (Act on the Protection of Irregularity Reporters/Whistleblowers), Narodne novine br. 17/19, available at: https:// www.zakon.hr/z/1927/Zakon-o-zaštiti-prijavitelja-nepravilnosti (accessed 10 December 2019).

Zakon o bankama (Banks Act), Narodne novine br. 84/02,141/06, accessed 10 December 2019 https://narodne-novine.nn.hr/clanci/sluzbeni/1998_12_161_1983. html).

Zakon o državnim službenicima (Civil Servants Act), Narodne novine br. No 92/05, 142/06, 77/07, 107/07, 27/08, 34/11, 49/11, 150/11, 34/12, 49/12, 37/13, 38/13, 01/15, 138/15, 61/17, 70/19, 98/19, available at: https://www.zakon.

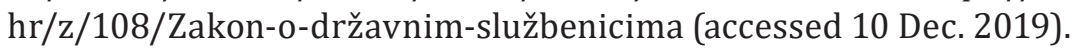

Zakon o radu (Labour Act), Narodne novine br. 93/14, 127/17, 98/19, available at: https://www.zakon.hr/z/307/Zakon-o-radu (accessed 10 December 2019).

Zakon o kaznenom postupku (Criminal Procedure Act), Narodne novine br. 152/08, 76/09, 80/11, 121/11, 91/12, 143/12, 56/13, 145/13, 152/14, 70/17, 126/19, 126/19, available at: https://www.zakon.hr/z/174/Zakon-o-kaznenompostupku (accessed 10 June 2019).

Zakon o službenicima i namještenicima u lokalnoj i područnoj (regionalnoj) samoupravi (Act on Civil Servants and State Employees in Local and Regional Self-Government), Narodne novine br. 86/08, 61/11, 04/18112/19, available at: https://www.zakon.hr/z/259/Zakon-o-službenicima-i-namještenicima-u-lokalnoj-i-područnoj-samoupravi (accessed 10 June 2019).

Zakon o trgovini (Trade Act), Narodne novine br. 87/08, 96/08, 116/08, 76/09, 114/11, 68/13, 30/14, 32/19, 98/19, available at: https://www.zakon.hr/z/175/ Zakon-o-trgovini (accessed 10 Dec. 2019).

Zakon o sustavu unutarnjih kontrola u javnom sektoru (Act on the Internal Financial Control System in the Public Sector), Narodne novine br. 78/15, 102/19, available at: https://www.zakon.hr/z/806/Zakon-o-sustavu-unutarnjih-kontrola-u-javnom-sektoru (accessed on 10 June 2019).

Zakon o zaštiti tajnosti podataka (Act on Protection of Data Confidentiality), Narodne novine 108/96, available at: https://www.zakon.hr/z/748/Zakon-ozaštiti-tajnosti-podataka (accessed 10 June 2019).

UK Employment Rights Act (1996); available at http://www.legislation.gov.uk/ ukpga/1996/18/contents (accessed 10 April 2018) 
UK Public Interest Disclosure Act (1998); available at http://www.legislation. gov.uk/ukpga/1998/23 (accessed 10 June 2017).

ECtHR and Croatian Case law

Guja v. Moldova (Application no 14277/04), Judgment of 12 February 2008; accessed 15 June 2019; https://hudoc.echr.coe.int/eng\#\{\%22fulltext\%22:[\%22142 77/04\%22],\%22documentcollectionid2\%22:[\%22GRANDCHAMBER\%22,\%22 CHAMBER\%22],\%22itemid\%22:[\%22001-85016\%22]\},

Heinisch v. Germany (Application no. 28274/08), Judgment of 21 July 2011, accessed 15 June 2019; https://hudoc.echr.coe.int/eng\#\{\%22fulltext\%22:[\%22282 74/08\%22],\%22documentcollectionid2\%22:[\%22GRANDCHAMBER\%22,\%22 CHAMBER\%22],\%22itemid\%22:[\%22001-105777\%22]\},

Bucur and Toma v. Romania (Application no. 40238/02), Judgment of 8 January 2013, available at: https://hudoc.echr.coe.int/eng\#\{\%22item id\%22:[\%22001-115844\%22]\}, accessed 15 June 2019.

Marunic v. Croatia (Application no. 51706/11), Judgment of 28 March 2017, accessed 15 June 2019 https://hudoc.echr.coe.int/eng\# \{\%22fulltext\%22:[\%225170 6/11\%22],\%22documentcollectionid $\% 22:[\% 22$ GRANDCHAMBER $\% 22, \% 22 \mathrm{CH}$ AMBER\%22],\%22itemid\%22:[\%22001-172322\%22]\},.

Martin and Others v. France (Application no. 30002/08), Judgment of 12 April 2012, available at: https://hudoc.echr.coe.int/eng\#\{\%22item id\%22:[\%22001-110306\%22]\}, accessed 15 June 2019.

Balenović v. Croatia, Application No. 28369/07, Judgment of 30 Sept. 2010, available at http://hudoc.echr.coe.int/eng\#\{“fulltext":[“28369"],"appno":[“28369/ 07"]\}, accessed 1 June 2018.

Presuda Općinskog suda u Zagrebu (Judgment of the Municipal Civil Court in Zagreb) (Z. Prpic) br. Pr-2721/01 of 14 April 2008.

Presuda Županijskog suda u Zagrebu (Judgment of the County Court in Zagreb) (Z. Prpic) br. Gžr-1440/11-4 of 28 December 2011.

Presuda Vrhovnog suda u Zagrebu (Judgment of the Supreme Court in Zagreb) (Z. Prpic) br. Revr-651/12 of 25 April 2012.

Odluka Ustavnog suda Republike Hrvatske (Decision of the Constitutional Court of Republic of Croatia) (Z.Prpic), Number: U-III-1142/2013 of 1 December 2014. 


\section{Doc. dr.sc. Helga Špadina,}

Docentica, Katedra radnopravnih i socijalnih znanosti,

Pravni fakultet Osijek, Sveučilište Josipa Juraja Strossmayera u Osijeku, Hrvatska

Marina Kalafatić,

Mag. iur. Osijek, Hrvatska

\section{PRAVNI POLOŽAJ I ZAŠTITA TZV. “ZVIŽDAČA” U RADNOM PRAVU}

\section{Sažetak}

Pravna zaštita tzv. zviždača (osoba koje otkriju ili podijele informacije o aktivnostima koje su nezakonite, neetične ili nepravilne unutar organizacije) u kontekstu radnih odnosa iznimno je delikatna tema koja ne prestaje privlačiti pažnju svih koji se bave izučavanjem suvremenog radnog prava. Kada je radnik spreman prijaviti koruptivno djelo, neophodno je aktivirati mehanizam pravne zaštite zviždača od nezakonitog otkaza i istovremeno, aktivirati postupak određivanja koruptivnog djela sa jasnim mehanizmom i mjerama radno pravne zaštite kako bi se izbjegle moguće zloupotrebe bilo od strane radnika, bilo od strane poslodavca. Ovaj rad istražuje pravnu regulativu zaštite prava zviždača u kontekstu komparativnog radnog prava i u kontekstu presuda Europskog suda za ljudska prava. Također analiziramo i najnovije napore Europske Unije u području pravne zaštite zviždača, kao i najvažnije europske pravne instrumente. Kroz pravnu zaštitu zviždača, države zapravo doprinose zaštiti javnog interesa, napretku dobre uprave i jačanju vladavine prava, kao i provedbi temeljnog demokratskog prava na slobodu izražavanja.

U Republici Hrvatskoj skoro svi javno poznati zviždači otpušteni su sa radnog mjesta zbog prijave nepravilnosti i do danas, samo je jedan od njih sudskom odlukom vraćen na posao. Nedavno usvojeni zakon o pravnoj zaštiti zviždača bi mogao doprinijeti promjenama u tom području i mogao bi osigurati dugo iščekivanu pravnu zaštitu svih koji prijave koruptivna kaznena djela na svom radnom mjestu.

Ključne riječi: zaštita zviždača, radno pravo, sloboda izražavanja. 
